Portland State University

PDXScholar

1979

\title{
Affirmative Action Programs in Social Service Agencies: Status of the Female M.S.W.
}

\author{
Geraldine Ann Berg \\ Portland State University \\ Katy Blanche Danner \\ Portland State University \\ Eileen Nolan Kressel \\ Portland State University \\ Sharon E. La Haie \\ Portland State University \\ Ellen McKeever \\ Portland State University
}

See next page for additional authors

Follow this and additional works at: https://pdxscholar.library.pdx.edu/open_access_etds

Part of the Labor and Employment Law Commons, and the Social Work Commons

Let us know how access to this document benefits you.

\section{Recommended Citation}

Berg, Geraldine Ann; Danner, Katy Blanche; Kressel, Eileen Nolan; La Haie, Sharon E.; McKeever, Ellen; Monteblanco, Petra; Plushnick, Joan Ann; and Wood, Carolyn V., "Affirmative Action Programs in Social Service Agencies: Status of the Female M.S.W." (1979). Dissertations and Theses. Paper 2825.

https://doi.org/10.15760/etd.2819

This Thesis is brought to you for free and open access. It has been accepted for inclusion in Dissertations and Theses by an authorized administrator of PDXScholar. Please contact us if we can make this document more accessible: pdxscholar@pdx.edu. 


\section{Author}

Geraldine Ann Berg, Katy Blanche Danner, Eileen Nolan Kressel, Sharon E. La Haie, Ellen McKeever, Petra Monteblanco, Joan Ann Plushnick, and Carolyn V. Wood 
AFFIRMATIVE ACTION PROGRAMS IN SOCIAL SERVICE AGENCIES: STATUS OF THE FEMALE M.S.W.

by

GERALDINE ANN BERG

ELLEN MCKEEVER

KATY BLANCHE DANNER

PETRA MONTEBLANCO

EILEEN NOLAN KRESSEL

JOAN ANN PLUSHNICK

SHARON E. LA HAIE

CAROLYN V. WOOD

A practicum submitted in partial fulfillment of the requirements for the degree of

MASTER OF SOCIAL WORK

Portland state University

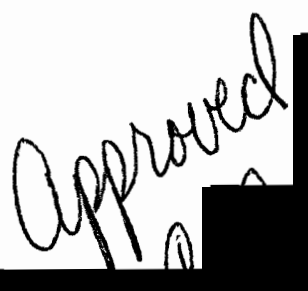




\section{ACKNOWLEDGMENTS}

We wish to acknowledge and thank the Oregon Chapter of the National Association of Social Workers for their support and encouragement of our project. We are particularly appreciative of the kindness and assistance of Marie Evans, Ruth Ann Sanstedt, Sue Swenson, and Mary Vandenberg, of the Women's Issues Committee of the Oregon Chapter of NASW. These persons were responsible for the design and completion of the first part of this research and provided us with much of the framework for the second part of the study.

We especially want to acknowledge our instructor, Dr. Sandra Anderson. She was, in our view, an equal member of this research group - providing both expertise and encouragement when ours was lacking, and maintaining a perspective of the overall research goals. We wish to thank her for providing us with a balanced environment in which we could learn: assistance to keep the project progressing steadily, and space for us to feel that we had accomplished something ourselves. 
TABLE OF CONTENTS

PAGE

ACKNOWLEDGMENTS......................

LIST OF TABLES.........................

CHAPTER

I. INTRODUCTION................... 1

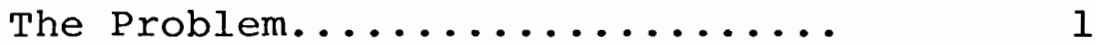

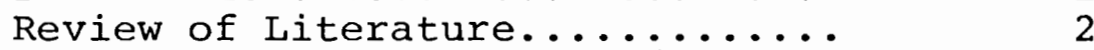

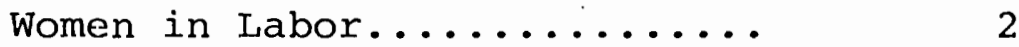

Women in Social Work................. 3

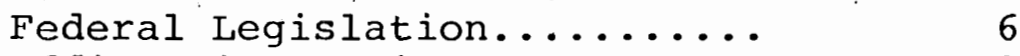

Affirmative Action.......... 8

Affirmative Action in

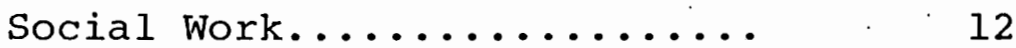

The Present Study: Part I....... 13

The Present Study: Part II...... 15

II METHODOLOGY................... 16

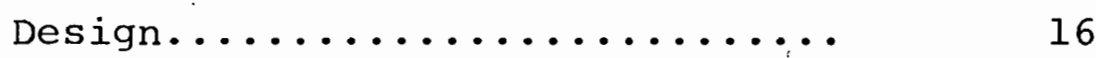

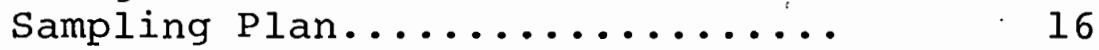

Data Gathering Methods.......... 18

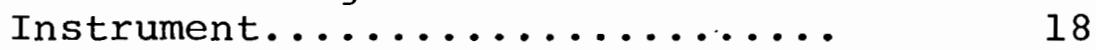

Data Analysis Plan............. 21

III $\quad$ FINDINGS.....................

Profile of Respondents.................... 23

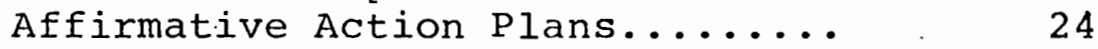

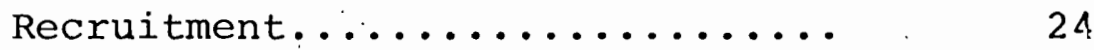

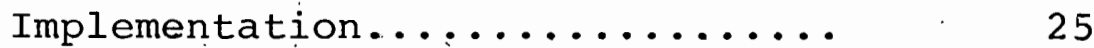

Implementation and Women MSWs.... 30

IV SUMMARY AND CONCLUSIONS............ 33

BIBLIOGRAPHY......................... 38 
PAGE

APPENDIX............................

TABLES.

INTRODUCTORY IETTER................

INSTRUMENT : QUESTIONNAIRE............ 


\section{CHAPTER I}

\section{INTRODUCTION}

\section{The Problem}

Job status and salary inequities between men and women have only recently been documented (Kravetz 1976). The federal government, over the past few decades, through various acts and executive orders, has created legislation to prohibit discrimination based on race, sex, color, religion or national origin in all employment practices. The question is to what extent this legislation has permeated social service agencies and affected their employment patterns, particularly with respect to administrative positions.

In 1976, the Women's Issues Committee of the Oregon Chapter of the National Association of Social Workers (NASW), addressed this question by initiating a study of social work employment in Oregon. The first part of the study examined the salaries and positions of NASW members in this state. The second part of the study was designed to study more specifically the employment patterns of women MSWs in Oregon's social service agencies. Under the auspices of the Women's Issues Committee, the second part of the study was designed and conducted by eight graduate 
students at the School of Social Work at Portland State University. One objective of the study was to find out the proportion of men and women filling the management positions in local social service agencies. But the primary purpose of the study was to examine the managementexecutive employment patterns in agencies before and after affirmative action programs were instituted. An attempt was then made to determine the effects, if any, of such programs. It was hoped that the results would clarify. how agencies implement their affirmative action programs, the effects of implementation, and the barriers to the employment of women in management positions.

Additional goals of the study, of particular importance to the Women's Issues Committee, were to use the information gathered in order to help agencies more effectively implement their (affirmative action programs) and to provide assistance in management training for those women interested in entering administrative positions.

Review of Literature

Women in Labor. Women have always worked, but their entry into the world of paid labor has a shorter history. In 1840 , it was reported that there were seven industries open to women (Rayne 1883). By 1883, the state of Massachusetts had announced that there were 284 occupations open to women, but professional positions were largely still unavailable. Teaching, nursing, and social work were 
among those few professions that were open to women, in part because they were seen as extensions of the traditional female role. But they were also open to women because of the pioneering efforts of their founders, radical and non-traditional women, who were seeking in some way to challenge the values of their society. Even in these professions, however, men often occupied positions involving administration, hiring and policy development (Kravetz 1976). Although the reasons for this practice were many, social definitions of roles were often significant factors in career choices and opportunities.

Over the years women increased their numbers in the labor force, expanded their earning power and widened the alternatives from which they might choose employment. 'In 1910, eight million women were included in the country's paid labor force, composing 21 percent of the labor market (Lyle 1973). By 1978, the Census Bureau reported that 41 million or 41 percent of the labor force were women. While women have always worked to supplement the family income or to support themselves and their family, today more people of both sexes are seeking employment which will enable them to realize personal, social and monetary recognition. Many women who support themselves and their families are seeking increased responsibility and challenge in their jobs (Jongward and Scott 1977).

Women in Social Work. Men and women alike often choose careers which extend and expand their own skills and 
interests. In our culture, because women are most often socialized for the important role of caring for others, the profession of social work has been a logical entrance point for women desiring a career outside of the home (Chavetz 1972). Social work as a profession stemmed from the voluntary charity workers, suffragists and reformers who sought to help the poor and the neglected (Kravetz 1976). It developed and continued to be seen as a "woman's profession" until shortly after World War II when the availability of the GI Bill for education and an effort by the profession to recruit men resulted in an increased enrollment of men in schools of social work (Scotch 1971, Chavetz 1972, Kravetz 1976, Szakacs 1977). In fact, however, as males became part of the profession, they entered the realms of community organization and administration in disproportionate numbers, and these areas became differentially valued and rewarded.

Despite the profession's efforts to recruit men, social work remains a "woman's profession" in terms of numbers. Two-thirds of the membership in the National Association of Social Workers is female. However, the division of labor within the profession and the wage benefits resulting from that division have resulted in men filling the higher status positions. In our society, management-executive positions usually offer more money, more challenge and more prestige. Whether administrative work should offer more status than direct service to people 
is, of course, both a philosophical and political question. The question is whether or not qualified and competent women are afforded an equal opportunity to fill administrative positions if they should so desire.

Nationally, two-thirds of the administrative positions in social work are held by men, even though women constitute two-thirds of NASW membership (Stamm 1969). A i 976 study of federally funded non-profit agencies throughout the United States found that 16 percent of the agencies were headed by women, a dramatic drop from. 60 percent in 1957 (Szakacs 1977, Flanagan 1977). This male domination of high status positions can be seen in social work schools as well as in practice. In 1973, more than half of the full-time faculty in accredited graduate schools of social work in the United States were men; 63 percent of the full and associate professors were men and, in 1975, 88 percent of the deans and directors of accredited graduate schools of social work were men. (Kravetz 1976). In one recent study which compared the salaries of men and women faculty members in schools of social work in the United States and Canada, it was found that differences in mean salaries of men and women persisted even when controlling for rank, doctorate, publications, experience, and ethnicity. The conclusion of this study is that "conventional criteria to determine salary levels are applied selectively to men and women faculty" (Gould and Kim 1976). Other 
researchers have controlled for job tenure, marital obligations and part-time employment and still found statistically significant differences in the salaries of males and females (Williams, Ho, and Felder 1974; Belon and Gould 1977). The available literature suggests that women are kept from top positions by three barriers: "internal conflicts regarding roles and careers; external pressures from family, friends and professionals; and continuing discriminatory practices within organizational structures" (Flanagan 1977, Chapman and Luthans 1975).

Federal Legislation. In an attempt to end discriminatory practices and to equalize opportunities for women and minorities within the labor market, the federal government instituted the Equal Pay Act in 1963 making it illegal for an employer to pay differentially on the basis of sex. According to this Act, employees of both sexes performing jobs requiring substantially equal skill, effort and responsibility under similar working conditions must be paid the same wages (Stead 1975). Although this Act did not cover employees in executive, administrative or professional categories, the 1972 Education Amendment extended coverage to include these categories of employees, including all those in public and private educational institutions (Jongward and Scott 1977).

The 1963 Equal Pay Act was followed in 1964 by the Civil Rights Act, known as Title VII, which forbids discrimination on the basis of race, color, sex, religion 
or national origin in all employment practices including hiring, firing, transfer, promotion, compensation, fringe benefits and other privileges and conditions of employment such as sick leave, vacations, overtime, and insurance (Babcock, Freedman, Norton, and Ross 1975; Jongward and Scott 1977; VanDyke and Cooke 1977).

An amendment in 1972 known as the Equal Employment Opportunity Act or Public Law 92-261, included all employers with twenty-five or more employees, all employment agencies, labor unions, state and local government agencies and public and private educational institutions. In 1973 the Act covered all employers with fifteen or more employees and all unions with fifteen or more members. With so many businesses and agencies affected, the Equal Employment Opportunity Commission (EEOC) published Guidelines on Discrimination Because of Sex which states that, "The principle of nondiscrimination requires that individuals be considered on the basis of individual capacities and not on the basis of any characteristics generally attributed to the group" (Jongward and Scott 1977). These guidelines, although not law, have been upheld in court and have been adopted in principle as a result of such cases as Diaz v. Pan American and Bowe v. Colgate Palmolive (VanDyke and Cooke 1977; Jongward and Scott 1977). A part of the EEOC's regulatory function is to provide a means for employees to report job related discrimination. It then 
may investigate, protect, conciliate, and/or file suit for the employee.

Following enactment of Title VII, in 1965 came Executive Order 11246, signed by President Johnson, prohibiting discrimination against minorities in employment. Amended and enacted as Executive order 11375, it also prohibits discrimination on the basis of sex. This order requires that all federal contractors, including educational institutions, with fifty employees and a contract of $\$ 50,000$ or more develop a written affirmative action plan which includes data and analysis of current employment figures, evaluation of ways to increase areas of underemployment and specific numerical goals and timetables for decreasing and eventually eliminating discrimination (Babcock, Freedman, Norton and Ross 1975).

This executive order is enforced by the U.S. Department of Labor under the office of Federal Contract Compliance Programs (OFCC). In 1970, Sex Discrimination Guidelines were issued. These were followed by Chapter 60, Part 60-2 of the Code of Federal Regulations known as Revised Order No. 4, which specifically sets out the requirements for the development of affirmative action programs and has been used as a model for most other plans.

Affirmative Action. Executive order 11246 and Revised Order No. 4 outline the steps necessary to initiate an 
effective affirmative action program with a committment to end discrimination. The first step is to collect employment statistics such as the number and percentage of women and minorities in each major job category; the number and percentage of these groups at each pay grade or salary level; the number and percentage of management jobs held by women and minorities; and the number and percentage of each group who are full-time, part-time, temporary or permanent employees (Jongward \& Scott 1977, US Civil Service Commission 1976).

The second area to evaluate is the available work force. Data needs to be collected regarding the number of women and minorities having the required skills in the general recruitment area, the number seeking employment, and the number in the work force. Qualified persons who are promotable within the organization also need to be identified in a systematic way and training provided for them to develop required skills for promotion (Jongward and Scott 1977, Stead 1975).

Once this data has been accumulated and analyzed along with the projected number of jobs that will become available, the agency or organization is ready to set data based goals and timetables to eliminate the now identified areas of underemployment. These timetables may extend up to a five year period, with planned intermediate targets. At this point, committment to action which will 
fulfill goals is necessary.

Several strategies can be developed for meeting employment goals in a given organization. Employment figures of the agency as well as of the general work force, of applicant flow, and of trends in turnovers and job expansion can continue to be charted. A second strategy is to analyze and revise recruitment policies and to eliminate explicit or implicit discrimination in advertisements, interviews, or places of recruitment (slevin 1971, Cunningham 1976).

When a larger pool of applicants has been recruited, the possibility for meeting selection goals is increased. The next important area becomes selection, followed by promotion policies. Once qualified persons have been found and hired it is essential that an agency provide equal pay for equal work, potential career paths, grievance procedures, and management training and development programs. Policies regarding salary, promotion, job posting, layoff and rehiring all need to be examined and evaluated for discriminatory practices (Slevin 1971; Babcock, Freedman, Norton, Ross 1975; Cunningham 1975; Kay 1976).

Developing an affirmative action program is a step by step process. Committment and motivation by top management and administration is essential (Almquist 1977). This committment may be manifested in the amount of resources and the degree of staffing and authority allocated 
to the affirmative action program (Cunningham 1976). Gathering data, setting appropriate goals, and developing strategies are time-consuming and often tedious tasks. Despite the fact that the above tasks may be completed, the attitudes of employers who allocate jobs and set salaries may hinder full implementation (Almquist 1977). Attitudes of male and female employees, managers, and administrators toward sex discrimination and towards female or minority leadership can make or break a program (Slevin 1971; Reif, Newstrom, Monszka 1975; Chapman and Luthans 1975; Almquist 1977).

Attitude change in an agency may be accomplished through sensitivity training, role playing, educational programs, small group discussions, team building or workshops (Slevin 1971). It may be accomplished as a result of built-in incentives such as monetary rewards (Cunningham 1976). Employers and employees must be motivated to take action, whether from a moral, humanistic, democratic, legal or monetary consideration.

Ideally, an effective and well implemented affirmative action plan will end the wasted resources and lost opportunities that businesses, universities, and agencies have subjected themselves to by limiting the employment and promotion of minorities and women. Additionally, they will avoid civil or federal lawsuits and unfavorable publicity. Affirmative action programs are relatively new. While 
goals have been set, many are not being met for a variety of reasons including incorrect assumptions and projections, restricted applicant flow, incomplete implementation, and lack of committment. In August 1977, the U. S. Civil Service Commission investigated thirty-one local United Way agencies for compliance with the nondiscrimination requirements of the Federal Fund Raising Manual and found that nineteen agencies needed modifications or updatés on affirmative action plans (McQuoid 1977).

Affirmative Action in Social Work. Businesses, organizations and agencies can look to the government, to one another, and to the literature for help in designing and implementing effective affirmative action programs. The National Association of Social Workers has developed a program that goes beyond the mere legal requirements of affirmative action. "The nature of our profession and the functions of our association indicate a moral obligation to take a leadership role in advocating equal rights and equal opportunity" (NASW Chapter Action Guide 1977). However, NASW stresses that moral considerations are only part of its motivation. With equal representation of minorities and women; NASW expects to strengthen its programs by broadening perspectives and increasing membership. Hiring women has not been an issue for most social service agencies since women numerically dominate the profession. However, the one area where goals are not being met is in administration and management (Cunningham 1975; 
Liss 1975; Hennig and Jardim 1976; Women's Issues Committee, NASW, R. I. Chapter 1975). In a 1975 study of ninety-eight social work agencies in Rhode Island "an obvious disparity between the number of professional social workers in the state and the number of administrative positions occupied by women" was cited. In addition, the lack of concern with this situation by administrators was noted (Women's Issues Committee, NASW, R. I. Chapter 1975). In Portland, Oregon the 1978 plan of the Multnomah County. Department of Human Services specifically mentions the need to increase the number of women and minorities in official and administrative positions. Besides implementation of career development programs for women, widespread recruiting and visible, accessible career ladders, the exposure of myths about women managers is necessary (Reif, Newstrom, Monczka 1975; Chapman and Luthans 1975; Kay 1976; Burke and Weir 1977; Jongward and Scott 1977).

The Present Study: Part I

Prompted by the recent studies documenting the decline of women MSWs in administrative positions (Flanagan 1977, Szakacs 1977), the Women's Issues Committee of the Oregon chapter of NASW initiated a study in March 1978 of social work employment in the state. A subcommittee consisting of Marie Evans, Ruth Ann Sanstedt, Sue Swensen and Mary Vandenberg gathered data on 278 NASW members through a self-administered employment questionnaire. The survey 
received a forty percent return rate and yielded much information on the differential employment patterns of female and male MSWs.

Patterned after Szakacs' $1977^{\prime}$ study, it was hypothesized that women are paid less than men with equal education, experience and administrative responsibility and that women are less satisfied with their jobs and perceive less opportunity for advancement than do men. The findings were that, with degree, experience and administrative responsibility held constant, salary levels were significantly related to sex, with upper levels dominated by men and lower levels by women $(p=.01)$. The median salary was $\$ 19,000$ for males and $\$ 15,000$ for females, a difference of $\$ 4,000$. It is significant to note that in 1968 there was only a $\$ 1500$ difference in the median salaries of male and female NASW members. Administrative responsibility was also found to be significantly related to sex, with high responsibility belonging to men and low responsibility levels dominated by women $(p=.01)$. This is particularly relevant since administrative responsibility was shown to be related to job satisfaction for women. That is, job dissatisfaction increases as administrative responsibility decreases $(p=.05)$. It was also found that job titles were significantly related to sex. Thus it was more likely that the title "director" would belong to a man and a "direct service" title would belong to a woman. In. 
view of the fact that direct service jobs pay significantly less, this is especially important. Differential job titles have functioned to maintain discriminatory practices in a number of other fields of employment.

Having established that the employment status of women MSWs in Oregon was consistent with results of studies conducted in other parts of the country. (Knapman 1977, Belon and Gould 1977), the Women's Issues Committee sought to further explore this issue by studying the implementation of affirmative action plans in social service agencies. In order to do this, a second phase of the study was initiated.

The Present Study: Part II

The second part of the oregon NASW study, conducted by eight MSW students at Portland State University, focused upon the implementation of affirmative action plans by social agencies in Oregon. More specifically, an examination was made of management-executive employment patterns before and after affirmative action programs were instituted. Management-executive positions were defined as those filled by persons who are responsible for (a) policy development (b) program development and (c) supervision. 
CHAPTER II

METHODOLOGY

$\underline{\text { Design }}$

The purpose of this descriptive study was to collect and analyze data pertaining to the relationship between affirmative action efforts in social service agencies and the employment patterns of women MSWs in managementexecutive positions. An examination was made of those agencies implementing an affirmative action program and the effect, if any, this had on the employment of women MSWs in management-executive positions.

As previously noted, this study was the second part of a research project completed by the Oregon . Chapter of NASW in March 1978 which examined the salaries and positions of NASW members in this state.

Sampling Plan

Population. The population consisted of all the social service agencies in Multnomah, Clackamas, Washington and Marion counties. Social service agencies were defined as agencies where MSWs are employed in some aspect of social service; direct service, protective service, community development, planning, research, or social work education. Listings of these agencies were obtained from the following 
directories: The Directory of Community Services (TriCounty Community Council), State Private Automatic Network (State Directory of Social Services), Salem Area Agency Telephone and Address List, Oregon Association of Hospitals. In addition, the Portland Public Schools were included in the population. The branches of large, umbrella agencies were included in the population rather than just the umbrella agency itself.

After compiling a list of all agencies in the population, agencies were classified as either public or private. A public agency was defined as one which was established by legislative action; a private agency was defined as one which was established by meeting the legal requirements of incorporation and licensing. Profit or proprietary agencies were not included in the population. The final population consisted of 117 public and 111 private agencies.

Sample. Proportionate sampling was used to select a representative sample of 15 percent of public and 15 percent of private agencies. In order to be included in the sample an agency had to meet the criteria of employing three or more full-time MSWs. This number was chosen as it seemed to reflect the minimum number needed to study potential promotion patterns in an agency. A random numbers table was used to select the sample. A total of 76 public agencies were drawn before 18 agencies meeting the criteria were identified. A total of 90 private agencies were drawn 
before 17 agencies meeting the criteria were identified. Out of the 35 agencies selected in this manner, one agency refused to grant an interview and four, upon further examination, did not meet the criteria of the study. Thus, the total sample consisted of 30 agencies: 15 public and 15 private.

\section{Data Gathering Methods}

An introductory letter was sent to the director of each agency in the sample (see appendix, p 48). The purpose of this letter was to familiarize the directors with the study and to request their participation in the study. One week after the letters were mailed, the director of each agency was contacted by telephone to schedule an appointment for an interview.

\section{Instrument}

Data was collected by means of a questionnaire verbally administered to the directors of each agency in the sample. In order to test our hypothesis, data was collected on the present number of management-executive positions in a given agency, whether or not the agency had implemented an affirmative action plan, the number of management-executive. positions at the time the plan was adopted, and the change, if any, in that number since the time the affirmative action plan was implemented. In addition, data was collected on exactly how and to what extent an agency imple- 
mented and monitored its affirmative action plan. In the final form of the questionnaire, questions were grouped under the following categories: Present Status; Guidelines; Implementation; Responsibility for Implementation; Audit, Report and Evaluation; Potential Barriers to the Employment of MSW Women in Management-Executive Positions. Development of the questionnaire was based upon a comprehensive review of affirmative action literature. The final questionnaire contained 70 questions (see appendix, p 49) and interviews ranged from 30-45 minutes.

In order to evaluate whether an agency is implementing its affirmative action plan, it was necessary to first establish the criteria by which implementation could be measured. These elements have been clearly delineated in Revised Order No. 4 of the Code of Federal Regulations and include data collection, pinpointing, goal setting, recruitment, promotion, personnel training, and awareness building. The first criterion of implementation is data collection. Records must be kept of the number and percentage of women who are in each job category, at each pay level, in management jobs, and who are not permanent or full-time. The questionnaire for this study asked executive directors to indicate which records they maintained for statistical purposes. (They were presented with eight options selected from the records required of agencies under United Way auspices.) Those agencies scoring above the mean were 
considered to be implementing data collection, those below the moan wore considored not to be implomenting. The second criterion of a program is pinpointing, or monitoring, reviewing and evaluating the data collected. The questionnaire asked whether agencies monitor and review the data they gather and whether top management meets regularly to evaluate such information. Agencies which both monitor and evaluate data on the status of affirmative action programs were considered to be implementing pinpointing.

The third criterion for implementation is goal setting. Comprehensive data collection and analysis should indicate the specific areas of underemployment in an agency and help to determine the necessary goals and timetables for addressing the imbalance. We asked the directors in this study whether they had any immediate goals regarding employment of women MSWs in management-executive positions, and, if "yes", what they were. A "yes" answer indicated implementation of goal setting.

The fourth implementation criterion involves the area of recruitment as the first step in meeting the organization's goals. Directors were asked if they actively recruited women MSWs for management or supervisory positions and, if so, where and how. Because recruitment and hiring are done at a state level in a large number of public agencies, this question could not be answered validly by many of those interviewed. Therefore, a decision was made 
to use the answers descriptively but not as a specific criterion for implementation.

The fifth implementation criterion is promotion, which provides another avenue for achieving employment goals. Directors were asked if management-executive positions are posted within the agency, and if there is a system for identifying qualified women MSWs within the agency. Affirmative answers to these two questions indicated implementation of promotion criterion. Answers to a third question, dealing with the existence of a structured advancement pattern for management-executive positions in the agency, were used descriptively.

Final elements of implementation include providing training and awareness building for employees. If the agency sponsored any management training and development seminars as well as any substantial attitude change efforts through group discussion or special seminars, it was considered to be meeting the personnel training criterion of implementation. Awareness building was considered implemented if affirmative action guidelines are distributed to every employee, if guidelines are distributed to those involved in recruitment and hiring, and if guidelines are discussed in appropriate management and supervisory meetings.

Data Analysis Plan

Since the instrument was precoded, data was transferred directly from the questionnaire to the computer cards. The 
data was analysed on a Harris 220 computer, using the spss program, which is a statistical package for the social sciences that allows extensive data manipulation and transformation, while the output is well labeled for ease of interpretation.

Throughout the study, a two tailed test was used. The Chi Square and Fisher Exact tests were used to determine whether to accept or reject the hypothesis that variables were independent within the population; if the p value was less than or equal to .05, the difference was considered significant. A t-test was used to compare group means, and that difference was considered significant if it was less than or equal to .05 .

Agency size was recoded into small (less than 30 employees), medium (30-50 employees) and large (50 or more employees). Given the previously stated criteria of implementation (i.e. pinpointing, awareness, promotion, training, data gathering and goals), a mean score for all agencies was tabulated. Any agency scoring equal to or above the mean (1.74) was considered to be implementing an affirmative action plan. The hypothesis was that agencies who are implementing an affirmative action plan will employ significantly more MSW women in management-executive positions than those who are not implementing a plan. 
CHAPTER III

\section{FINDINGS}

The 30 agencies utilized in the study employ five to 404 personnel and employ three to 18 MSWs. Overall, they have an average of 55 employees and an average of nine fulltime MSWs. Women constitute over two-thirds of all employees of these agencies, and about two-thirds of all MSWs employed are women.

In 97 percent (29) of the agencies, MSWs are considered eligible for management-executive positions including that of executive director. However, only one half (15) of these agencies reported having a structured advancement pattern for management-executive positions. In 14 of these agencies the pattern was considered common knowledge. The advancement pattern was acknowledged by written policy in 13 agencies, announcements in meetings in 13, posting the procedure in 12, and by other means such as memorandums, flyers and job advertisements in six of these agencies.

\section{Profile of Respondents}

The 30 agency administrators interviewed were either program or executive directors. A majority of these respondents, 83 percent (25), were men and only 17 percent (five) were women. One-third (11) of these directors were 
also in charge of the affirmative action program in their agency. In the vast majority of cases, final promotion and hiring decisions were made by the director (53 percent) or shared with department heads, division managers or boards (33 percent).

Affirmative Action Plans

Ninety percent (27) of the 30 agencies studied have written affirmative action plans and the average agency has had a plan in effect for four years. The majority of lagencies have utilized federal and/or state guidelines as sources of their plans $(60$ percent used federal and 67 percent used state guidelines), but one-third (nine) have developed their own guidelines and one-fourth (seven) have utilized United Way guidelines.

\section{Recruitment}

The 30 agencies recruited employees for managementexecutive positions in various ways. Management-executive openings are advertised locally by two-thirds (20) of the agencies. Of these 20, advertising was done in other agencies by 13, in the local media by 11 , in the NASW newsletter by nine, at the NASW chapter office by seven, and at the Portland State University School of Social Work by five of these agencies. Ten of the agencies advertised through other local sources such as the state employment office, workshops, other schools and by word of mouth. 
Twenty-three percent (seven) of the agencies advertised management-executive positions nationally. Four advertised in the NASW news, four advertised in schools of social work, and two used other professional journals such as AMA publications and educational journals. Five agencies used other national sources such as United Way, National Association for Retarded Citizens and the American Psychological Association.

Only 27 percent (eight) of the 30 agencies reported that they actively recruit MSWs for management or supervisory positions. Agency recruitment practices were not used as an affirmative action implementation criterion since the recruitment statistics are affected by the requirement that public agencies hire from civil service lists.

\section{Implementation}

The first objective of the study was to determine whether. or not agencies with written guidelines were meeting minimal federal criteria of implementation. Thus, specific questions were formulated to evaluate data collection, promotional practices, pinpointing, training programs, awareness (attitude change) efforts and goal setting. In the following paragraphs the percentages of agencies meeting each criterion are given (see Table I, p 45). Only the 27 agencies with written affirmative action plans are included in the implementation statistics. 
Forty-eight percent (13) of the agencies met data gathering criteria. Fifty-six percent (15) maintained statistics on new employees by job classification and sex. Thirty-seven percent (10) recorded applicant flow by sex; promotion by job classification and sex; turnover by job classification, sex and the reason for turnover; change in composition of the organization work force by type of job and level of management as these relate to the affirmative action program goals; and/or changes being made to the affirmative action program as a result of the activities during the reporting year. One-third (nine) recorded rejections by sex and the reasons for those rejections and only 26 percent (seven) maintained statistics on employee participation in organization training programs by sex.

Forty-four percent (12) of the agencies met promotion criteria. Agencies meeting promotion criteria posted management-executive positions within the agency and had a system for identifying qualified women MSWs within the agency. Management-executive positions were posted within the agencies in 78 percent (21) of those surveyed. A lesser number, 56 percent (15) of the respondents said they had a system for identifying qualified MSWs within their agency. For most of the agencies the system is informal; that is, the director knows the qualifications and performance of propsective individuals.

Forty-one percent (11) of the agencies met pinpointing 
criteria. Of the 27 agencies with written plans, 70 percent (19) monitored and reviewed the statistics gathered. Twenty-six percent (seven) monitored and reviewed these statistics annually, 15 percent (four) did so semi-annually and 15 percent (four) did so quarterly. Nineteen percent (five) indicated other times for review such as weekly or as often as deemed necessary. However, top management meets to receive and evaluate information on the status of the affirmative action program in only 48 percent (13) of the agencies. Twenty-two percent (six) of top managers meet annually, 11 percent (three) semi-annually, seven percent (two) meet quarterly and 15 percent (four) meet at other times to receive and evaluate this information. Nineteen percent (five) of the agencies met training criteria. Sixty-three percent (17) had sponsored management training and development seminars in the past year. Twenty-nine percent of the seminar participants had been women MSWs. Since affirmative action program implementation, only 30 percent (eight) of the agencies had engaged in any substantial attitude change efforts in the area of affirmative action.

Nineteen percent (five) of the agencies met awareness criteria. Eighty-nine percent (24) of the agencies distributed affirmative action guidelines to those directly involved in recruitment and hiring, 82 percent (22) included guidelines in the personnel manual and a smaller number, 56 
percent (15) distributed them to every employee. Guidelines are discussed in appropriate management and supervisory meetings in 85 percent (23), in employee orientation in 63 percent (17), in training programs in 56 percent (15), during recruitment and interviewing in 52 percent (14) and in other areas in 22 percent (six) of the agencies.

Seven percent (2) of the agencies met goal setting criteria. In those agencies with immediate goals for the employment of women MSWs in management-executive positions, one administrator was looking for a woman supervisor and another said a woman MSW would be recruited if there were any openings in the agency.

No agency in the study met more than four of the six implementation criteria. Seven percent (two) of the agencies met four criteria, 18 percent (five) met three, 30 percent (eight) met two, 30 percent (eight) met one, and 15 percent (four) did not meet any of the federal criteria of implementation. In summary, the vast majority (75 percent) of agencies met less than one-half of the criteria deemed essential to the implementation of an affirmative action plan. Agencies were most likely to meet criteria involving data gathering, pinpointing and promotional practices (41-48 percent di.d so), and were least likely to meet criteria involving goal setting, training and awareness efforts. In essence, less than one-half of the agencies maintain, monitor and evaluate adequate records for affirmative action 
purposes, post management-executive positions within the agency, and have a system for identifying qualified women MSWs within the agency. Only 19 percent (five) of the agencies have engaged in any substantial attitude change efforts. Finally, only seven percent (two) of the agencies have immediate goals regarding the employment of women MSWs in management-executive positions.

None of the criteria of implementation are significantly related to agency size; although the majority of agencies meeting data gathering and pinpointing criteria are large agencies (over 50 employees). Agencies with fewer than 30 employees were least likely to meet criteria involving promotional practices, and no small agency met the training criteria of implementation. In addition, public agencies were significantly more likely to meet data gathering and training criteria (see Tables. II and III, pp $45 \& 46)$. In fact, no private agency in the study met the training criterion.

Given this relatively low rate of implementation, it is helpful to explore the relative status of these programs within agencies. Only seven percent (2) of the agencies have a separate budget item for affirmative action implementation, and this item is an extremely small percentage of the total budget. In spite of this, 78 percent (21) of the agencies with plans have a specific person in charge of their affirmative action program. These individuals have a multitude of additional responsibilities, and less than 
one-third (eight) of them have the authority to implement changes in policy and practice. Incentives for implementation are provided by only 37 percent (10) of the agencies, and these most commonly include supervisory evaluation, verbal recognition, and time off for workshops or conferences. Only two agencies cited promotion as an incentive for implementation.

In summary of the first objective of the study, the evaluation of minimal criteria of implementation, it was found that a minority of agencies is meeting even onehalf of the federal criteria. Criteria involving data gathering, pinpointing and promotional practices are more likely to be met than those involving goal setting, training and attitude change efforts: And finally, public agencies and those with more than 50 employees tend to meet more criteria than private and much smaller agencies.

\section{Implementation and Women MSWs}

The second objective of the study was to explore the relationship between implementation and the number of management-executive positions filled by women MSWs. When the six criteria were evaluated individually, none was shown to be significantly related to management positions filled by women MSWs since affirmative action programs were initiated or to the number of women MSWs in these positions currently. Neither were agency auspice or size related to the filling of these positions. Thus, individual implementation 
criteria and agency auspice and size have little or no relationship to the number of management positions filled by female MSWs.

This part of the study dealt with changes in employment patterns since the initiation of affirmative action programs. Since programs have begun, there has been a slight but insignificant increase in the number of management-executive positions in agencies. There has, however, been no significant change in the number of women MSWs filling these positions. Slight, but insignificant, gains were made by non-MSW women and male MSWs and even greater ones were made by non-MSW men. The female MSW has actually lost a little ground since affirmative action plans were initiated (see Table IV, p 46). They occupied 35 percent of management positions when plans were initiated, and they currently occupy 28 percent of these positions. When agencies were analyzed individually, it was found that 37 percent (10) have the same number of women MSWs as when their plan was initiated, 33 percent (nine) have fewer, and 30 percent (eight) have more currently.

In an attempt to examine further the relationship between implementation and women in management positions, the group mean on the implementation criteria was usea to divide the agencies into two groups. Thus, agencies above and below the mean were compared in terms of size, auspice and number of female administrators. Agency size was not 
found to be related to implementation and, while public agencies tend to meet more criteria than private agencies, this difference did not reach the level of significance acceptable in the study $(p=.09)$.

When their affirmative action plan was initiated, agencies currently meeting more criteria did not differ from other agencies in total number of management positions or in the number of female MSWs occupying these positions. At the present time, however, agencies meeting more criteria tend to have more management positions than agencies meeting fewer criteria $(p=.06)$. In spite of this, they have not tended to fill these new positions with female MSWs. At the present time, in agencies meeting more implementation criteria, women MSWs constitute 26 percent of all managementexecutive personnel, while in agencies meeting fewer criteria, 32 percent of management-executive positions are filled by women MSWs. This difference is not significant, and is in the opposite direction of that hypothesized. In essence, the meeting of implementation criteria is not positively related to the number of female MSWs in management positions. The mean number of women MSW executives in agencies meeting more criteria is 1.6 and the mean number in agencies meeting fewer criteria is 1.3. The former agencies have more management-executive positions, and this is not a significant difference (see Table V, p 47). 


\section{CHAPTER IV}

\section{SUMMARY AND CONCLUSIONS}

Female MSWs in Oregon are paid less and have less administrative responsibility and lower job satisfaction than male MSWs. Since the initiation of affirmative action programs in the state, there has been an impressive maintenance of the status quo. There have been no significant gains by any group, but most have been made by nonMSW males and least by MSW females.

The majority of agencies have written plans, but relatively few meet even one-half of the minimal federal criteria for implementation. The areas most neglected by agencies are goal setting, training and efforts directed toward attitude change. Public agencies and those with more than 50 employees tend to meet more criteria than private and smaller agencies. But even agencies which meet some of the criteria do not employ significantly more female MSWs in executive positions than agencies meeting few or no criteria. In fact, they employ a smaller proportion of female MSWs in executive positions than do agencies meeting fewer criteria. A separate budget item for affirmative action is extremely rare and a minority of affirmative action officers receive incentives for implementation or have the authority to initiate changes in 
policy or practice.

These data raise more questions than they answer about sex inequalities, lack of program implementation, and the apparent impotence of existing plans. Agency administrators were asked specifically about barriers to attaining management-executive positions by women MSWs in their agencies, and their responses are revealing. The most frequently cited barrier (mentioned by 57 percent of agencies) is insufficient opportunity for upward mobility. While the average agency currently has five managementexecutive positions, it also has an average of 17 employees eligible for these positions. Interestingly, the majority of those eligible are non-MSWs, predominately women. The next most cited barrier to female MSWs, mentioned by 40 percent of agencies, is inadequate training and preparation outside of the agency. It appears that many MSW women lack the prerequisite knowledge and skills essential to compete for the relatively few management-executive positions. Finally, 20 percent of agencies cited inadequate training in management and supervision within the agency as a potential barrier to female MSWs. Relatively few agencies cited insufficient affirmative action budget, employee resistance, lack of committment or limited recruitment of eligible women as barriers. Other impediments, mentioned by few, were societal attitudes about sex roles, women's lack of interest in management positions and, stated directly, a tendency. to hire men for higher 
level positions.

The final study question asked the administrator to discuss specific difficulties encountered in implementing the agency's affirmative action plan. Forty-three percent reported no difficulties in implementing their respective plans. The remaining directors identified several barriers to implementation. The first factor mentioned was institutional racism, in conjunction with a lack of applications from properly trained minorities. In addition, low salaries and the need for more time were seen as problems in implementation. One director believed that affirmative action programs are of limited value considering societal values and sex roles. Several interviewees discussed difficulties relating to community acceptance of a woman discussing an agency budget and her inability to relate to male colleagues of larger agencies. One director pointed to a pervasive tendency to maintain men in higher positions, hiring or promoting women only under compulsion of law. In conjunction with this, one director stated that there are ways of working with civil service lists and hiring whomever you wish.

In summary, several barriers to implementation are most obvious. These include limited opportunities for upward mobility and inadequate training in administration, particularly for minorities. In addition, institutional sexism and racism can lead to the circumvention of the most 
impressive affirmative action plan.

Regarding the issue of inadequate training, numerous authors have emphasized the need for graduate school recruitment of women in the planning and management track as well as management training programs for female graduates. There is no data base to support the viewpoint that women and other minorities are innately less capable of performing competently as managers.

An equally important issue is that of attitude. Negative attitudes can make or break any affirmative action program. Attitude change within agencies may be accomplished through sensitivity training, role playing, educational programs, small group discussions or, if humanistic motivation is lacking, through legal or monetary constraints. In addition, educators can work to eliminate the teaching of sexist theories and methods in graduate schools of social work. Kravetz (1976) has pointed out that stereotypical views of female development and traditional sex-role standards provide the theoretical framework for much of social work knowledge. Theories steeped in sex bias affect the type of data gathered from clients, the standards for assessing behavior, and the formulation of treatment goals. Thus, the uncritical teaching and application of such theories to practice may have a profoundly negative effect upon clients. Mental health professionals have been severly criticized in recent years for perpetuating an adjustment-oriented notion of health that limits women's oppor- 
tunities for personal growth and full participation in society. The elimination of sexism in social work will be aided by each individual's opportunity to re-examine his or her values and beliefs about women, become aware of the devastating effects of sexism, and reassess biased assumptions in the literature. Schools of social work can play a significant role in these endeavors. The time for affirmative action has come and it is imperative that the social work profession take a leadership role in this area so reflective of social work values. 


\section{A SELECTED BIBLIOGRAPHY}

"Acting Affirmatively to End Job Bias." Business Week, 27 January 1975, pp. 94-99.

"Affirmative Action Consultants Employed." NASW News, May 1978 , p. 7 .

Almquist, Elizabeth M. "Women in Labor Force," Signs: Journal of Women in Culture and Society 2 (Summer 1977): 843-855.

Babcock, Barbara; Ann Freedman; Elenor Norton; and Susan Ross. Sex Discrimination and the Law: Causes and Remedies. Boston: Little, Brown and Co., 1975.

Bakke, Louise S. and Jean B. Edson. "Women in Management: Moving Up?" Social Work 22 (November 1977):512-514.

Behman, Sara. "Affirmative Action v. Seniority: The Affirmative Action Position." Labor Law Journal 27 (August 1976): 490-497.

Belon, Cynthia J. and Ketayun H. Gould. "Not Even Equals: Sex-related Salary Inequities." Social Work 22 (November 1977):466-472.

Brager, George and John A. Michael. "The Sex Distribution in Social Work: Causes and Consequences." Social Casework 50 (December 1969): 597 .

Burke, Ronald J. and Tamara Weir. "Readying the Sexes for Women in Management." Business Horizons 20 (June 1977) : 30-35.

Chafetz, Janet S. "Women in Social Work." Social Work 17 (September 1972):12-18.

Chapman, J. Brad and Fred Luthans. "Female Leadership Dilemma.". Public Personnel Management 4 (May/June 1975) : 173-179.

Cohen, David. "An End to Affirmative Action?" Labor Law Journà 28 (April 1977):218-229.

Cunningham, John. "Avoiding Common Pitfalls in Affirmative Action Programs." Personnel Journal 55 (March 1976): 125-127. 
Daddio, Saundra. "Oh! The Obstacle to Women in Management." In Affirmative Action for Women: A Practical Guide for Women and Management, pp. 153-172. Edited by Dorothy Jongward and Dru Scott. Massachusetts: Addison-Wesley Publishing Co., 1977.

Diangson, P.; D. F. Kravetz; and J. Lipton. "Sex Role Stereotyping and Social Work Education." Journal of Education for Social Work 11 (Fall 1975):44-49.

Dodd, William and Michael Pesi. "Readying the Sexes for Women in Management." Business Horizons 20 (January 1977) : 30-35.

Epstein, Cynthia F. Woman's Place, Options and Limits in Professional Careers. Berkeley: University of California Press, 1971.

Fanshel, Davis. "Status Differentials: Men and Women in Social Work." Social Work 21 (November 1976):448-454.

Featherman, David L. and Robert M. Hauser. "Sexual Inequalities and Socioeconomic Achievement in the U. S. 1962-1973." American Sociological Review 41 (June $1976): 462-483$.

Ferber, Marianne A. and Helen M. Lowry. "The Sex Differential in Earnings: A Reappraisal.". Industrial and Labor Relations Review 29 (April 1976):377-387.

Flanagan, Mary. "Women in Social Work: Perceptions of Barriers to Administrative Advancement, Part I." Woman Power, December 1977, pp. 3-4.

"Women in Social Work: Perceptions of Barriers
to Administrative Advancement, Part II." Woman
Power, May 1978, pp. 5-7.

Francke, Chester A. "Perceived Performance Differences Between Women and Men Supervisors and Implications for Training." Dissertation Abstracts International 36 (September 1975):1344-1350.

Fuchs, Victor. "Differences in Hourly Earnings Between Men and Women." In Woman in a Man-Made World, pp. 222227. Edited by Nona Glazer-Malbin and Helen Youngelson Waehrer. Chicago: Rand McNally \& Co., 1972.

Garland, Howard and Ken Price. "Attitudes Toward Women in Management and Attributions for Their Success and Failure in a Managerial Positions." Journal of Applied Psychology 62 (February 1977):29-33. 
Gould, Ketayun and Bok-Lim C. Kim. "Salary Inequalities Between Men and Women in Schools of Social Work: Myth or Reality?" Journal of Education for Social Work 12 (Winter $197 \overline{6): 50-55 .}$

Gripton, James. "Sexism in Social Work: Male Takeover of a Female Profession." The Social Worker 42 (Summer $1974): 78-89$.

Hennig, Margaret and Anne Jardim. "How to Make Room at the Top." Psychology Today, January 1977, pp. 80-93.

Herberg, Dorothy C. "A Study of Work Participation by Graduate Female Social Workers: Some Implications for Profesional Social Work Training." Journal of Education for Social Work 9 (Fall 1973): 16-23.

Hulett, Sarah. "Women Administrators in Missouri." School and Community 63 (January 1977):16.

Jongward, Dorothy and Dru Scott. Affirmative Action for Women: A Practical Guide for Women and Management. Massachusetts: Addison-Wesley Publishing Co., 1977.

Kay, Janice. "Career Development for Women: An Affirmative Action First." Training and Development Journal

30 (May 1976) :22-25.

Kadushin, Alfred. "Men in a Woman's Profession." Social Work 21 (November 1976):440-447.

Knapman, Shirley Keuhnle. "Sex Discrimination in Family Agencies." Social Work 22 (November 1977):461-465.

Kundsin, Ruth B., ed. Women and Success: The Anatomy of Achievement. New York: William Morrow \& Co.\% 1974.

Koch, J. V. and J. F. Chizmar. "Sex Discrimination and Affirmative Action in Faculty Salaries." Economic Inquiry XIV (March 1976):16-24.

Kravetz, Diane. "Sexism in a Woman's Profession." Social Work 21 (November 1976):421-426.

Lemmon, Cynthia Belon and Katayun H. Gould. "A Survey of the Career Patterns and Salary Differences of the Social Workers in the Illini Unit of the Illinois State Chapter." Woman Power, February 1977, pp. 1-3.

Liss, Lora. "Why Academic Women Do Not Revolt--Implications for Affirmative Action." Sex Roles I (September 1975): 209-223. 
Longres, John and Robert Bailey. "Men's Issues and Sexism: A Journal Review." Social Work 24 (January 1979): 26-32.

Lyle, Jerolyn R. Affirmative Action Programs for Women: A Survey of Innovative Programs. Equal Employment Opportunity Commission. Washington, D. C., 1973.

McQuoid, George J. Letter to Associate Director of FundRaising Operations of United Way of America. 5 August 1977 .

Miller; Jo. "Inequalities in the Organizational Experience of Men and Women." Social Forces 54 (December 1975): 365-381.

Moran, Robert D. "Reducing Discrimination: Role of the Equal Pay Act." In Woman in a Man-Made World, pp. 238-244. Edited by Nona Glazer-Malbin and Helen Youngelson Waehrer. Chicago: Rand McNally \& Co., 1972.

Multnomah County Department of Human Services, Affirmative Action Plan, Portland, Oregon, 1978.

NASW. Chapter Action Guide, Washington, D. C., October 1978.

National Association of Social Workers. Rhode Island

Chapter. Ninety-eight Agencies: Sexism in Social Work conducted by Women's Issues Committee. Rhode Island, 1976 .

Ozawa, Martha N. "Women and Work." Social Work 21 (November 1976): 455-462.

Rayne, Martha Louise. What Can A Woman Do? Or Her Position in the Business and Literary World. Chicago: F. B. Dickerson \& Co., 1883 .

Reich, Stephen and Andrew Geller. "Self-Image of Social Workers." Psychological Reports 39 (October 1976): 657-658.

Reif, William E.; John W. Newstrom; and Robert M. Monczka. "Exploding Some Myths About Women Managers." California Management Review XVII (Summer 1975):72-79.

Schwartz, Mary C. "Sexism in the Social Work Curriculum." Journal of Education for Social Work 10 (Fall 1974): $65-70$.

Scotch, C. Bernard. "Sex Status in Social Work: Grist for Women's Liberation." Social Work 16 (July 1971): 5-11. 
Silvestri, Marco J. and Paul I. Kane. "How Affirmative is Action for Administrative Positions in Higher Education?" Journal of Higher Education XLVI (July) August 1975):445-450.

Slevin, Dennis. "What Companies are Doing About Women's Job Equality." Personnel 48 (July/August 1971):8-18.

"Social Workers Charge State with Sex Bias." NASW NewS, May $1977, \mathrm{p} .7$ :

Stamm, Alfred M. "NASW Membership: Characteristics; Deployment and Salaries." Personnel Information 12 (May 1969) : 34-45.

State of Oregon. Affirmative Action Plan. Salem, Oregon, 1978 .

Stead, Bette Ann. "Educating Women for Administration." Business Horizons 18 (April 1975): 5i-56.

"Survey Indicates Social Work Women Losing Ground in Leadership Ranks." NASW News, April 1977, p. 12.

Szakacs, Juliana. "Is Social Work a Women's Profession?" Woman Power, February 1977, pp. 1-3.

Terborg, James R. "Women in Management: A Research Review." Journal of Applied Psychology 62 (December 1977) : $647-\overline{664}$.

Underwood, Osta. "Legislation and Litigation: Impact on Working Women." In Affirmative Action for Women, pp. 42-70. Edited by Dorothy Jongward and Dru Scott. Massachusetts: Addison-Wesley Publishing Co., 1977.

U. S. Civil Service Commission. Affirmative Action Plan Outline. Washington, D. C. , 1977 .

\section{Goals and Timetables for Effective Affirmative} Action. Washington, D. C., 1976 .

United Way of the Columbia Willamette. Affirmative Action Program. Portland, Oregon, 1977.

Van Dyke, Jane A. and Jenny L. Cooke. Equal Employment Opportunity Resource Handbook. Portland, Oregon; 1977.

Williams, Martha; Liz Ho; and Lucy Felder. More Grist for Women's Liberation." (July 1974) : 463-466.
"Career Patterns: Social Work 19 
"Women Administrators Found Unequal in Pay, Status." Chronicle of Education, 27 June 1977, p. 8.

"Women's Liberation Counts a Victory." Business Week, 13 June 1970, pp. 98-100.

Zietz, Dorothy and John L. Erlich. "Sexism in Social Agencies." Social Work 21 (November 1976):434-439. 
APPENDIX 
TABLE I

AGENCIES MEETING IMPLEMENTATION CRITERIA

$(\mathrm{N}=30$ Agencies $)$

Criteria

Pinpointing

Awareness

Promotion

Data Gathering

Training

Goals
Number

11

5

12

13

5

2
Percent

41

19

44

48

19

7

TABLE II

AUSPICE AND DATA GATHERING CRITERIA

(Percent Distribution)

\begin{tabular}{lccc}
$\begin{array}{c}\text { Data Gathering } \\
\text { Criteria }\end{array}$ & $\begin{array}{c}\text { PUBLIC } \\
(\mathrm{N}=13)\end{array}$ & $\begin{array}{c}\text { PRIVATE } \\
(\mathrm{N}=14)\end{array}$ & $\begin{array}{c}\text { TOTAL } \\
(\mathrm{N}=27)\end{array}$ \\
\hline $\begin{array}{l}\text { Agencies meeting } \\
\text { criteria }\end{array}$ & 71.4 & 23.1 & 48.1 \\
$\begin{array}{c}\text { Agencies not meeting } \\
\text { criteria }\end{array}$ & 28.6 & 76.9 & 51.9
\end{tabular}

Fisher's. Exact Test $p=.02$ 
TABLE III

AUSPICE AND TRAINING CRITERIA

(Percent Distribution)

Training Criteria

PUBLIC

Agencies meeting

criteria

Agencies not meeting

criteria
$(\mathrm{N}=13)$

35.7

00.0

18.5

PRIVATE

$(\mathrm{N}=14)$

TOTAL

$(\mathrm{N}=27)$

64.3

100.0

81.5

Fisher's Exact Test $p=.02$

TABLE IV

MANAGEMENT-EXECUTIVE POSITIONS

(Percent Distribution)

Sex \& Degree

Men non-MSW

Men MSW

Women non-MSW

Women MSW
When Plan Initiated

19

22

24

35
Currently

25

23

25

28 


\section{TABLE V}

\section{IMPLEMENTATION AND WOMEN MSWS IN MANAGEMENT-EXECUTIVE POSITIONS}

\begin{tabular}{lccc} 
& $\begin{array}{c}\text { Agencies } \\
\text { Implementing } \\
\text { Plan (N=15) }\end{array}$ & $\begin{array}{c}\text { Agencies not } \\
\text { Implementing } \\
\text { Plan (N=12) }\end{array}$ & $\mathrm{P}^{\mathrm{a}}$ \\
\hline Mean Number of & 1.6 & 1.3 & .60 \\
Women MSWs & & &
\end{tabular}

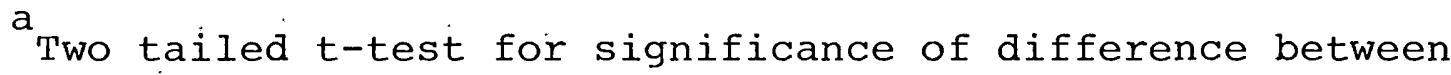
means. Agencies implementing plans have more management positions, and women MSWs constitute 26 percent of all their management personnel. In agencies meeting fewer criteria, 32 percent of management positions are filled by women MSWs. 
January 22, 1979

Dear

In conjunction with graduate social work students at Portland State University, we are currently collecting data for the second part of the study initiated by this chapter last year. The first part of the study examined the salaries and positions. of NASW members in this state. This part of the research addresses the relationship. between Affirmative Action efforts and employment patterns of women in management-executive positions.

In order to arrive at an accurate assessment of these employment patterns, we need the cooperation of randomly selected social work agencies in a four county area of the state. We ask for your assistance in this endeavor.

Graduate social work students will be conducting one hour interviews with directors of agencies beginning February 1, 1979. You will be receiving a call from a student within the next week to discuss any questions you may have about the research and make arrangements for an interview.

We appreciate your cooperation and will be happy to furnish you with a summary of the findings at your request.

Sincerely,

Don Oxford, President Oregon Chapter, NASW

$\mathrm{kd}$ 
AFFIRMATIVE ACTION AND SOCIAL WORK AGENCIES

On Multiple Cols $\mathrm{DK}=99(9)$

DNA $=98(8)$

\section{Present Status}

1. What is the name of your agency?

cols $1-2=$ case number; $\operatorname{col} 3=$ card number

2. Is your agency private or public?

private $=1 ;$ public $=2$

3. What is your title?

don't precode

4. Sex of respondent.

female $=1 ;$ male $=2$

5. What is the total number of employees in your agency?

6. What number are women?

7. What number are MSWs?

8. How many are women MSWs?

9. Are MSWs eligible for management-executive (M/E) positions in your agency?

$$
\text { yes }=1 ; \text { no }=2 ; \mathrm{DK}=3
$$

We define management-executive positions as those filled by persons who are responsible for (a) policy development (b) program development and (c) supervision.

10. Are MSWs eligible for the position of executive director of your agency?

$$
\text { yes }=1 ; \text { no }=2 ; . \mathrm{DK}=3
$$

11. What is the total number of $\mathrm{M} / \mathrm{E}$ positions in your agency?

12. What number are women?

13. What number are MSWs?

14. How many are women MSWs?

15. Is there a structured advancement pattern for $M / E$ positions in your agency?

yes $=1 ;$ no $=2 ; \mathrm{DK}=3$ 
16. If yes, how is it acknowledged?

$$
\text { yes }=1 ; \text { no }=2 ; \text { DK }=3
$$

a. posted

b. written policy

c. announced in meetings

d. common knowledge

e. other

17. What are the current number of employees eligible for management or executive positions in your agency?

18. How many of these are women?

19. How many are MSWs?

20. How many of these are women MSWs?

21. Who makes the final decision regarding promotion and hiring in this agency? don't precode

\section{Guidelines}

22. Do you have written Affirmative Action guidelines? yes $=1 ;$ no $=2 ; \mathrm{DK}=3$

23. When were your Affirmative Action guidelines first adopted as policy?

code month and year, i.e., 0177

24. What is the source of your guidelines?

yes $=1 ;$ no $=2 ; \mathrm{DK}=3 ; \mathrm{DNA}=9$

a. Federal government

b. State government

c. United Good Neighbors

d. Affirmative Action officer

e. Equal Employment Opportunity Commission

f. Office of Federal Contract Compliance in the Department of Labor 
g. State or city human Rights agencies

h. Own

i. Other

25. Are the guidelines distributed to every employee? yes $=1 ;$ no $=2 ;$ DK $=.3$

26. Are the guidelines distributed to those directly involved in recruitment and hiring?

yes $=1 ;$ no $=2 ; \mathrm{DK}=3$

27. Are the guidelines included in the personnel manual? yes $=1 ;$ no $=2 ;$ DK $=3$

28. Are the guidelines discussed

yes $=1 ;$ no $=2 ;$ DK $=3$

a. in employee orientation?

b. in training programs?

c. in appropriate management and supervisory meetings?

d. during recruitment and interviewing?

e. other

\section{Implementation}

29. At the time your AA guidelines were adopted, what was the total number of $\mathrm{M} / \mathrm{E}$ positions in your agency?

30. How many of these positions were filled by women?

31. How many of these positions were filled by MSWs?

32. How many of these positions were filled by women MSWs?

33. Since your AA program has been in effect, how many $M / E$ positions have been filled?

34. How many of these positions have been filled by women?

35. How many of these positions have been filled by MSWs?

36. How many of these positions have been filled by women MSWs? 
code case number (1-2) and card number (3)

37. How many of these positions have been filled from within the agency?

38. How many of these positions have been filled from outside the agency?

39. Are M/E positions posted within your agency? yes $=1 ;$ no $=2 ;$ DK $=3$

40. Are $M / E$ positions advertised locally? yes $=1 ;$ no $=2 ;$ DK $=3$

41. If yes, where do you advertise?

$$
\text { yes }=1 ; \text { no }=2 ; \mathrm{DK}=3
$$

a. NASW chapter office

b. NASW newsletter

c. PSU School of Social Work

d. local media

e. other agencies

f. other

42. Are $M / E$ positions advertised nationally?

$$
\text { yes }=1 ; \text { no }=2 ; \mathrm{DK}=3
$$

43. If yes, where do you advertise?

yes $=1 ;$ no $=2 ; \mathrm{DK}=3$
a. NASW news
b. schools of social work
c. other professional journals -- name
d. other

44. Are women MSWs actively recruited for management or supervisory positions?

$$
\text { yes }=1 ; \text { no }=2 ; D K=3
$$

45. If yes, how?

$$
\text { don't precode }
$$

46. Do you have a system for identifying qualified women MSWs within your agency?

$$
\text { yes }=1 ; \text { no }=2 ; \mathrm{DK}=3
$$


47. If yes, how?

don't precode

48. Were any management training and development seminars sponsored by your agency in the past year?

$$
\text { yes }=1 ; \text { no }=2 ; \text { DK }=3
$$

49. If yes, what percentage of the participants were women MSWs?

50. Since your $A A$ program has been implemented, have you engaged in any substantial attitude change efforts, for example, through group discussion, special seminars, etc.?

$$
\text { yes }=1 ; \text { no }=2 ; \text { DK }=3
$$

51. Do you have any immediate goals regarding the employment of women MSWs in $\mathrm{M} / \mathrm{E}$ positions in your agency? yes $=1 ;$ no $=2 ; D K=3$

52. If yes, what are they? don't precode

Responsibility for Implementation

53. Is there a specific person in charge of the AA program in your agency?

$$
\text { yes }=1 ; \text { no }=2 ; \text { DK }=3
$$

54. If yes, what is the job title of this person? don't precode

55. What other job responsibilities does this person have? don't precode

56. Does this person have the authority to implement changes in policy and practice?

$$
\text { yes }=1 ; \text { no }=2 ; D K=3
$$

57. Does this person report directly to

$$
\text { yes }=1 ; \text { no }=2 ; \text { DK }=3
$$

a. an executive administrator?

b. a committee?

c. the personnel director?

d. other 
58. If there a separate budget item for the AA program implementation?

$$
\text { yes }=1 ; \text { no }=2 ; D K=3
$$

59. If yes, what percentage of the budge is it?

60. Are incentives provided for the $A A$ officer for implementing the AA program?

$$
\text { yes }=1 ; \text { no }=2 ; D K=3
$$

61. If yes, which do you do?

$$
\text { yes }=1 ; \text { no }=2 ; \text { DK }=3
$$

a. evaluation by supervisory staff?

b. verbal recognition?

c. written recognition?

d. monetary reward?

e. promotion?

f. time off for conference or workshop attendance?

g. paid expenses for conferences or workshops?

h. other

62. Are incentives provided for other managers, supervisors, or policy makers for cooperating with the AA program

or equal opportunity policy? yes $=1 ;$ no $=2 ; \mathrm{DK}=3$

63. If yes, which do you do? yes $=1 ;$ no $=2 ; D K=3$

a. evaluation by supervisory staff?

b. verbal recognition?

c. written recognition?

d. monetary reward?

e. promotion?

f. time off for conference or workshop attendance?

g. paid expenses for conferences or workshops?

h. other 
Audit, Report and Evaluation

64. Which of the following records do you maintain for statistical purposes?

$$
\text { yes }=1 ; \text { no }=2 ; \text { DK }=3
$$

a. applicant flow by sex

b. new employees by job classification, sex

c. rejections by sex and the reasons for those rejections

d. promotion by job classification, sex

e. turnover by job classification, sex and the reason for turnover

f. employee participation in organization training programs by sex

g. changes in composition of the organization work force by type of job and level of management as these relate to the AA program goals

h. changes being made to the $A A$ program as a result of the activities during the reporting year

65. Are these statistics monitored and reviewed?

$$
\text { yes }=1 ; \text { no }=2 ; \mathrm{DK}=3
$$

66. If yes, does this occur
a. quarterly?
b. semi-annually?
c. annually?
d. other

67. Does top management meet to receive and evaluate information on the status of the Affirmative Action program?

$$
\text { yes }=1 ; \text { no }=2 ; \mathrm{DK}=3
$$

68. If yes, does this occur

$$
\begin{aligned}
& \text { a. quarterly? ( } 1 \text { ) } \\
& \text { b. semi-annually? }
\end{aligned}
$$


c. annually?
d. other

Potential Barriers to the Employment of MSW Women in M/E Positions

69. In terms of management and executive positions, which

of the following do you perceive as potential barriers

to women MSWs in your agency?

yes $=1 ;$ no $=2 ; \mathrm{DK}=3$

a. limited recruitment of eligible women by the agency

b. insufficient opportunities for upward mobility

c. lack of grievance procedures for women denied promotion

d. inadequate hiring goals

e. inadequate training in management or supervision within the agency

f. inadequate training and preparation of women outside the agency

g. insufficient budget for implementing an $A A$ program effectively

h. resistance by male employees

i. resistance by female employees

j. competition for qualified applicants

k. lack of commitment to affirmative action

1. lack of familiarity with the law

m. lack of adequate child care facilities

n. other

70. What difficulties have you experienced in implementing your agency's Affirmative Action plan? don't precode 